\title{
Unjuk Kerja Kolektor Surya Pelat Datar Aliran Paralel
}

\author{
Zulfa $^{1}$, Amrizal $^{2}$, dan Amrul ${ }^{2}$ \\ ${ }^{1}$ Balai Riset dan Standardisasi Industri (Baristand) Lampung \\ Jl. By Pass Soekarno Hatta Km. 1, Raja Basa Bandar Lampung - 35144 \\ ${ }^{2}$ Jurusan Teknik Mesin Fakultas Teknik Universitas Lampung \\ Jl. Sumantri Brojonegoro No. 1 Bandar Lampung \\ E-mail: zulfa_006@yahoo.co.id
}

\begin{abstract}
The performance of flat plate thermal solar collectors has been tested using an indoor solar simulator based on EN 12575-2: 2006. The aim of this research is to characterize the thermal performance of solar collector in the form of efficiency and pressure drop based on variation of distance between tubes to diameter of tube (W/D) and fluid flow direction (vertical and horizontal). Three collectors are made with copper plates of the same size. The variations of W/D used in this study are 8 for both collectors with horizontal and vertical flows and 12 for collector with vertical flow. Multiple Linear Regression (MLR) is required to characterize collector performance parameters in terms of zero efficiency and heat loss coefficients. The collector with $W / D 8$ vertical flow has the best performance from efficiency 46,65\% and heat loss with value 2,7111 W/ (m2K). Meanwhile the collector with W/D 12 for vertical flow has the best pressure drop with value of $123.48 \mathrm{~Pa}$. The vertical arrangement collector has the best performance in terms of heat loss coefficient and thermal efficiency but has a higher pressure drop value compared to the horizontal arrangement collector. The collectors with glass cover and smaller mass flow rates have the best performance in terms of heat loss and efficiency coefficients.
\end{abstract}

Keywords: Thermal efficiency, EN 12975-2: 2006, Flat plate solar collector, Pressure drop

\begin{abstract}
Abstrak
Unjuk kerja dari kolektor termal surya pelat datar aliran paralel telah diuji menggunakan solar simulator berdasarkan standar pengujian EN 12975-2:2006. Tujuan penelitian ini adalah untuk mengkarakterisasi unjuk kerja termal kolektor surya aliran paralel berupa efisiensi dan pressure drop berdasarkan variasi jarak antara pipa paralel terhadap diameter pipa (W/D) dan arah aliran fluida pada pipa riser (vertikal dan horizontal). Tiga buah kolektor dibuat dengan pelat tembaga yang berukuran sama. Variasi ukuran W/D kolektor adalah 8 untuk kedua jenis aliran baik secara horizontal maupun vertikal serta 12 untuk aliran secara vertikal. Multiple Linear Regression (MLR) diperlukan untuk mengkarakterisasi parameter unjuk kerja kolektor berupa efisiensi zero dan koefisien rugi kalor. Kolektor dengan W/D 8 aliran vertikal memiliki unjuk kerja terbaik dari sisi efisiensi sebesar 46,65 \% dan rugi-rugi kalor dengan nilai $2.7111 \mathrm{~W} /\left(\mathrm{m}^{2} \mathrm{~K}\right)$. Sementara itu kolektor dengan W/D 12 untuk aliran vertikal memiliki pressure drop terbaik dengan nilai 123.48 Pa. Kolektor susunan vertikal memiliki unjuk kerja terbaik dari sisi koefisien kerugian panas dan efisiensi termal akan tetapi memiliki nilai pressure drop lebih tinggi dibandingkan dengan kolektor susunan horizontal. Kolektor yang menggunakan penutup kaca dan kolektor dengan laju aliran massa yang lebih kecil memiliki unjuk kerja terbaik dari sisi koefisien kerugian panas dan efisiensi.
\end{abstract}

Kata kunci: Efisiensi termal, EN 12975-2:2006, Kolektor surya pelat datar, Pressure drop.

\section{PENDAHULUAN}

Indonesia merupakan negara yang terletak di daerah tropis dan khatulistiwa sehingga bumi indonesia mendapatkan sinar matahari dengan intensitas yang dapat dikatakan konstan dan cukup tinggi. Potensi energi panas matahari di Indonesia sekitar 4,8 kWh/m².hari atau setara dengan 112 ribu GWp. Namun, saat ini energi matahari yang sudah dimanfaatkan hanya sekitar 49 MWp. Ini berarti, potensi energi matahari yang sudah dimanfaatkan masih jauh dari angka $1 \%$ [1].

Penggunaan energi surya sebagai bentuk energi alternatif dapat digunakan secara luas pada sistem pemanas dan pendingin air, sistem pemanas dan pendingin ruangan, sumber listrik, dan bermacam proses industri. Penggunaan energi alternatif memberikan tiga keuntungan yakni hemat energi, membuka lapangan pekerjaan baru dan penurunan 
pencemaran lingkungan [2].

Salah satu jenis kolektor surya yang memiliki banyak kelebihan adalah kolektor surya plat datar, kelebihannya adalah dapat memanfaatkan komponen radiasi matahari berupa sorotan langsung dan sebaran, tidak memerlukan tracking matahari, desainnya yang sederhana, sedikit memerlukan perawatan dan biaya pembuatan yang murah. Pada umumnya kolektor jenis ini digunakan untuk memanaskan ruangan dalam rumah, pengkondisian udara, dan proses-proses pemanasan dalam industri [3].

Konfigurasi dari kolektor surya pelat datar merupakan parameter paling penting yang mempengaruhi performa dari kolektor. Banyak konfigurasi dari solar kolektor, yang paling umum digunakan adalah kolektor pipa paralel [4].

Konfigurasi lain seperti jarak pipa riser, arah aliran, pelat absorber, pakai kaca penutup dan tanpa kaca penutup juga sangat mempengaruhi performa kolektor. Jarak antara pipa riser berbanding terbalik dengan faktor efisiensi dari kolektor [1,5-9].

Distribusi aliran yang tidak seragam dipengaruhi oleh konfigurasi bentuk susunan pipa riser dan arah aliran, hal ini berpengaruh pada performa dari kolektor [10-13]. Pengujian dengan variasi pelat absorber juga telah dilakukan, yang menyarankan penggunaan pelat absorber aluminium sebagai pengganti pelat tembaga [14].

Penelitian-penelitian terdahulu tentang kolektor surya pelat datar aliran paralel selalu menggunakan header, sehingga kolektor jenis ini sering disebut dengan header riser collector. Diameter header selalu lebih besar daripada diameter pipa riser. Tetapi pada penelitian ini diameter pipa header yang digunakan sama dengan diameter pipa riser. Hal ini dilakukan karena tujuan lebih lanjut dari penelitian ini adalah menggabungkan kolektor dengan penel surya. Diameter header yang berbeda dengan diameter pipa riser menyebabkan penempelan kolektor pada panel surya tidak sempurna artinya timbul jarak antara pipa riser dan panel surya sehingga perpindahan panasnya tidak sempurna. Untuk itu perlu diketahui terlebih dahulu karakteristik dari kolektor surya pelat datar aliran paralel menggunakan pipa riser dan pipa header dengan diameter yang sama.

Pengabungan panel surya dengan kolektor surya pelat datar dilakukan untuk menurunkankan panas panel surya yang menyebabkan menurunnya efisiensi panel surya. Untuk itu diperlukan kolektor termal surya yang dapat menyerap panas dari panel surya tersebut [15]. Menurut Bonifacius dan Nurhamdoko [16] radiasi matahari dapat memanaskan interior dan modul PV itu sendiri. Pemanasan interior akan menurunkan kualitas termal sedangkan pemanasan modul PV menurunkan daya listrik yang dihasilkan.

Literatur diatas menjadi landasan dalam penyusunan penelitian ini. Penelitian ini bertujuan menguji karakteristik kolektor surya pelat datar aliran paralel berupa efisiensi thermal dan pressure drop berdasarkan pengaruh jarak antar pipa riser, susunan pipa riser, kaca penutup, dan laju aliran massa. Pengkajian ini penting karena efisiensi thermal yang tinggi menunjukkan besarnya kalor yang dapat ditransfer oleh kolektor sedangkan pressure drop sebaliknya, $\Delta \mathrm{P}$ tinggi membutuhkan kinerja pompa yang tinggi sehingga butuh daya listrik yang tinggi pula.

\section{METODOLOGI}

Penelitian ini dibagi menjadi tiga tahapan, yaitu pembuatan, pengujian dan analisis unjuk kerja termal kolektor. Kolektor termal dibuat sebanyak 3 unit menggunakan pelat tembaga dengan ukuran W/D masing-masing 8 untuk aliran vertikal dan horizontal serta 12 untuk aliran vertikal, seperti terlihat pada Gambar 1.

Metode pengujian yang digunakan adalah standar EN 12975-2:2006, menggunakan solar simulator (Gambar 2.). Pengujian dilakukan pada laju aliran $0,009167 \mathrm{~kg} / \mathrm{s}$ sesuai dengan luas kolektor $0,4576 \mathrm{~m}^{2}$ dengan variasi suhu air masuk kolektor 30, 40, 50 dan $60{ }^{\circ} \mathrm{C}$ menggunakan heater dengan thermostat.

Data-data temperatur diukur menggunakan Multi chanel thermometer data logger dengan 3 buah termokopel, yang diseting terekam setiap sepuluh detik selama lebih kurang $4 \mathrm{x}$ time konstan. Data temperatur yang direkam meliputi fluida masuk $\left(\mathrm{T}_{\mathrm{fi}}\right)$, fluida keluar $\left(\mathrm{T}_{\mathrm{fo}}\right)$, ambien $\left(\mathrm{T}_{\mathrm{a}}\right)$. Intensitas radiasi $(\mathrm{S})$ diukur menggunakan solarimeter pada awal dan akhir pengujian. Sedangkan pressure drop menggunkan $U$ tube differensial pressure Gauge. 


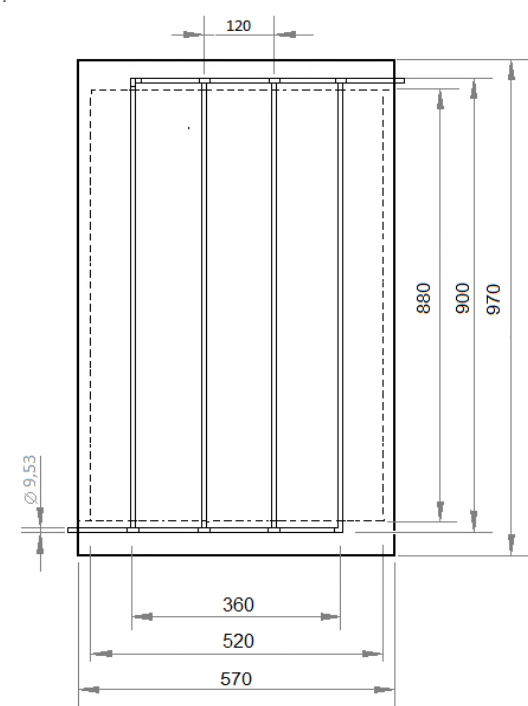

(a)

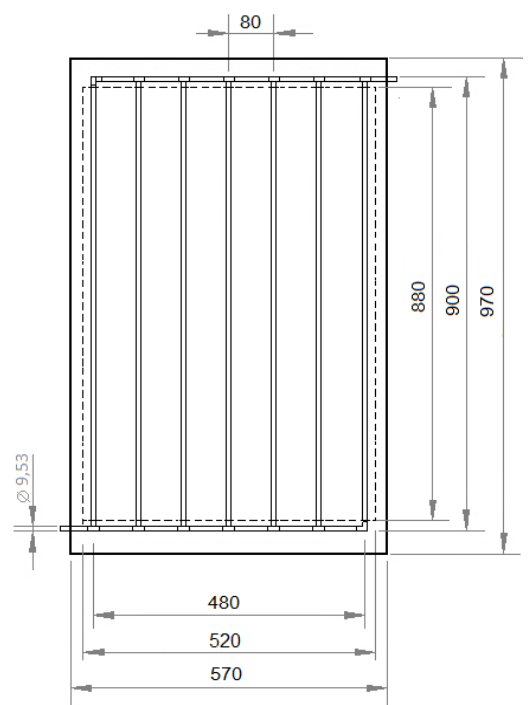

(b)

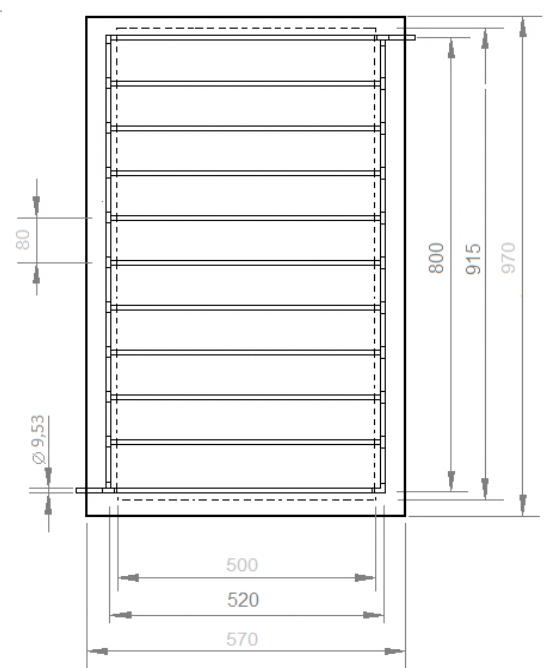

(c)

Gambar 1.Rancangan Kolektor (a) W/D=12 Vertikal, (b) W/D=8 Vertikal dan (c) W/D=8 Horizontal.

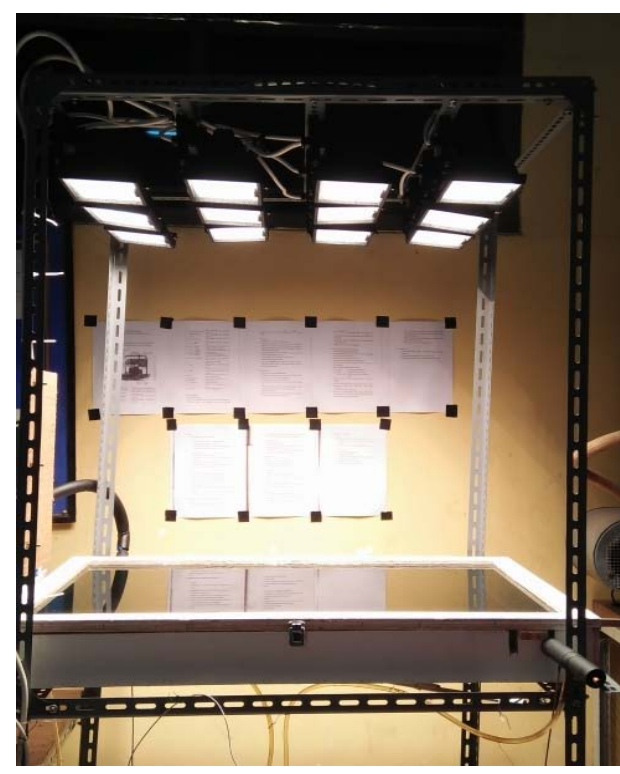

Gambar 2. Solar Simulator.

\section{HASIL DAN PEMBAHASAN}

\section{Pengaruh Variasi Jarak Pipa Riser}

Dari Gambar 3 diketahui semakin tinggi rugirugi panas maka efisiensi kolektor akan ikut turun, tetapi rugi-rugi panas sebanding dengan temperatur masuk dari fluida kolektor. Artinya pada suhu fluida masuk rendah kemampuan untuk menyerap energi panas masih tinggi dan menurun seiring dengan dinaikkannya temperatur fluida masuk kolektor.

Efisiensi dan rugi-rugi panas kolektor $\mathrm{W} / \mathrm{D}=8$ mm dan W/D=12 masing-masing adalah 46,6 : 36,9 $\%$ dan 2.7111:2.8655 $\mathrm{W} /\left(\mathrm{m}^{2} \mathrm{~K}\right)$. Hasil ini menunjukkan semakin dekat jarak antar pipa riser maka semakin tinggi efisiensi termal dan energi yang hilang akan semakin sedikit. Jarak antar pipa yang dekat berarti jumlah pipa akan semakin banyak ini berarti kontak perpindahan panas akan semakin besar. Nilai pressure drop kolektor $\mathrm{W} / \mathrm{D}=8 \mathrm{~mm}$ dan 120 mm masing-masing 246,96 Pa dan 123.48 Pa.

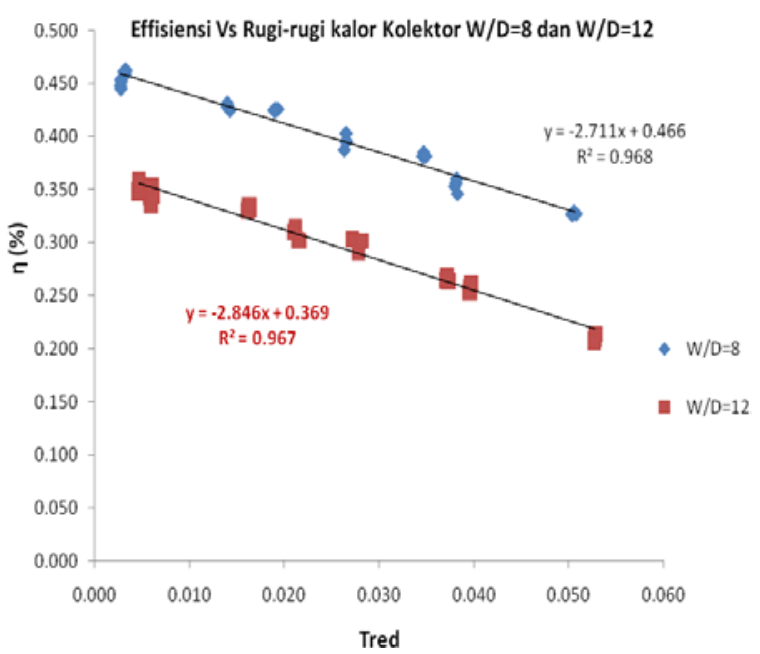

Gambar 3. Grafik efisiensi terhadap rugi-rugi kalor kolektor $\mathrm{W} / \mathrm{D}=8$ dan $\mathrm{W} / \mathrm{D}=12$.

Efisiensi kolektor tertinggi pada penelitian ini sebesar 46,65 \%. Nilai ini masih tergolong rendah jika dibandingkan dengan kolektor konvensional (kolektor dengan header yang lebih besar dari pipa riser/kolektor komersial). Nilai efisiensi kolektor konvensional rata-rata berkisar $60-80 \%$. Salah satu hasil pengujian kolektor pelat datar milik Solar 
Technologie International oleh TUV Rheinland memiliki efisiensi 79,5 \% dengan rugi-rugi panas $3.342 \mathrm{~W} /\left(\mathrm{m}^{2} \mathrm{~K}\right)$.

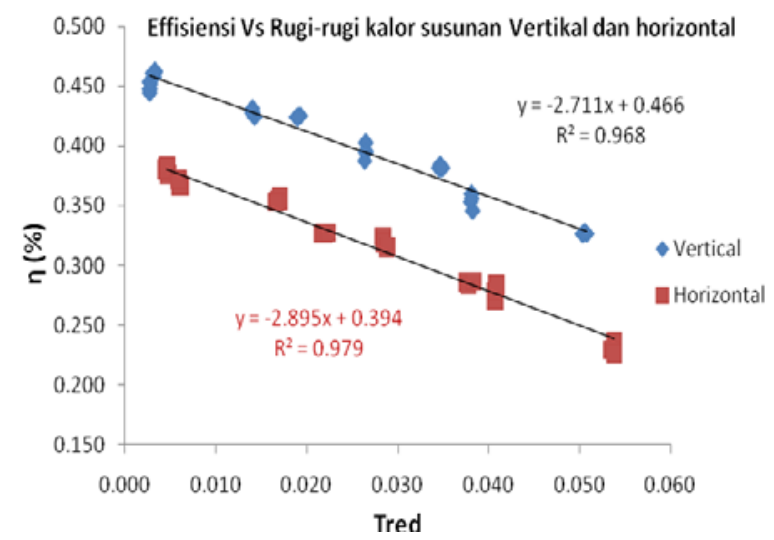

Gambar 4. Grafik efisiensi terhadap rugi-rugi panas kolektor sununan vertikal dan horizontal

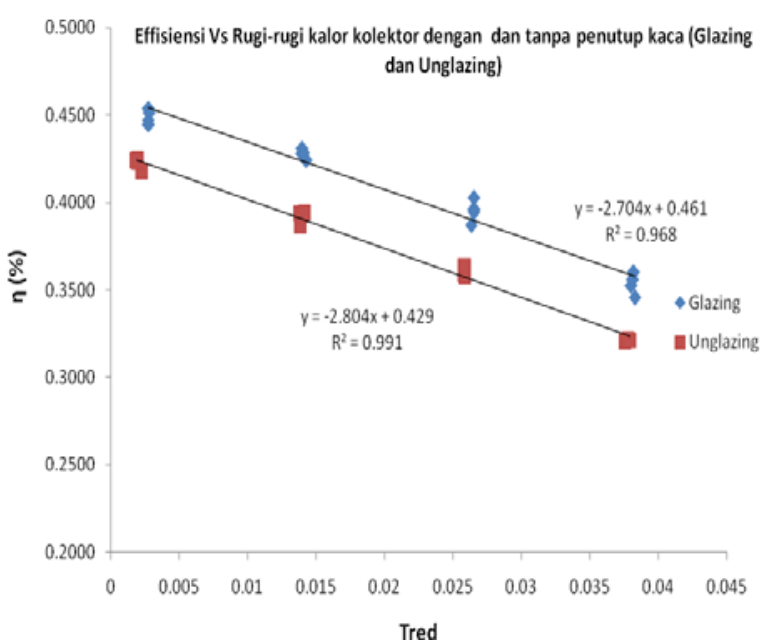

Gambar 5. Grafik efisiensi terhadap rugi-rugi kalor kolektor glazing dan unglazing.

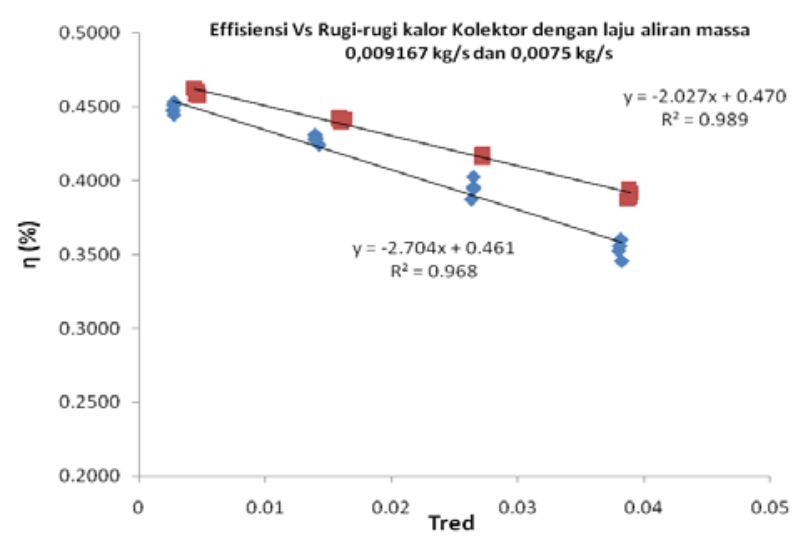

Gambar 6. Grafik efisiensi terhadap rugi-rugi kalor kolektor pada laju aliran massa 0,009167 kg/s. dan 0,0075 kg/s.

\section{Pengaruh Arah Pipa Riser}

Dari Gambar 4 diketahui efisiensi dan rugi-rugi kalor kolektor susunan vertikal dan horizontal masing-masing adalah 46,6 : 39,4 \% dan 2.711 : $2.895 \mathrm{~W} /\left(\mathrm{m}^{2} \mathrm{~K}\right)$. Hasil ini menunjukan bahwa kolektor dengan susunan arah pipa vertikal memiliki efisiensi dan kehilangan panas yang baik. Nilai pressure drop kolektor vertikal adalah 246,96 $\mathrm{Pa}$ dan horizontal 185,22 Pa. Hal ini menunjukkan di dalam rangkaian vertikal, terjadi hambatan yang lebih besar sehingga air yang ada didalam kolektor lebih tertahan yang menyebabkan perpindahan panas lebih lama pada fluida yang sama dibanding air yang ada dirangkaian horizontal, sehingga efisiensi termal nya lebih tinggi.

\section{Pengaruh Kaca Penutup}

Dari Gambar 5 diketahui efisiensi dan rugi-rugi kalor kolektor pakai kaca penutup dan tanpa kaca penutup masing-masing adalah 46,1 : 42,9 \% dan $2.704: 2.804 \mathrm{~W} /\left(\mathrm{m}^{2} \mathrm{~K}\right)$. Hasil ini menunjukkan bahwa kolektor dengan pakai kaca penutup memiliki efisiensi dan kehilangan panas yang baik. Hal ini menunjukkan dengan adanya penutup kaca kehilangan panas dari kolektor semakin kecil karena udara dan temperature lingkungan mempengaruhi perpindahan panas pada kolektor. Namun pada penelitian ini kehilangan panasnya masih tergolong kecil karena pengujiannya didalam ruangan (indoor).

\section{Pengaruh Laju Aliran Massa}

Dari Gambar 6 diketahui efisiensi dan rugi-rugi kalor kolektor pada laju aliran massa 0,009167 kg/s dan $0,0075 \mathrm{~kg} / \mathrm{s}$ masing-masing adalah 46,1 : 47,0 \% dan $2.704: 2.027 \mathrm{~W} /\left(\mathrm{m}^{2} \mathrm{~K}\right)$. Hasil ini menunjukkan bahwa kolektor dengan pakai kaca penutup memiliki efisiensi dan kehilangan panas yang baik. Hal ini menunjukkan penyerapan energi pada aliran 0,0075 $\mathrm{kg} / \mathrm{s}$ lebih tinggi daripada laju aliran $0,009167 \mathrm{~kg} / \mathrm{s}$ hal ini terjadi karena laju alirannya lebih kecil sehingga alirannya lebih lambat atau lama didalam pipa riser sehingga waktu kontak fluida dengan energi panas lebih lama sehingga temperatur keluar fluidanya lebih tinggi dan efisiensinya sedikit lebih baik. Nilai pressure drop pada pada laju aliran 0,009167 kg/s dan 0,0075 kg/s masing masing adalah 246,96 Pa dan 185.22 Pa.

\section{Analisa Pressure Drop}

Pressure drop hasil pengujian semua jenis kolektor tergolong sangat kecil hal ini diperkirakan karena aliran tidak terdistribusi secara merata disemua bagian pipa, air cenderung keluar melalui saluran yang lurus atau terdekat ke bagian keluar kolektor. Menurut Dunkle and Davey [17] jika aliran 
didalam pipa riser tidak seragam maka untuk mendapatkan performa kolektor yang lebih baik maka penting dibuat header pada kolektor tersebut karena aliran pada header bagian bawah masih turbulen ketika masuk pipa riser sudah laminar dan seterusnya diteruskan ke header untuk selanjutnya keluar dari kolektor.

Unjuk kerja termal dari kolektor pelat datar sangat dipengaruhi oleh susunan pipa riser dan header karena mempengaruhi distribusi aliran [3]. Distribusi aliran yang tidak diperhatikan bisa menyebabkan ketidakseragaman aliran yang dapat menurunkan efisiensi lebih dari $20 \%$ [18].

\section{Analisa statistik}

Berdasarkan Tabel 2 yang merupakan rangkuman hasil uji statistik semua jenis pengujian menujukkan bahwa hipotesa nol ditolak. Semua parameter yang berhubungan dengan temperatur reduksi dan efisiensi seperti temperatur masuk $\left(T_{\text {in }}\right)$, temperatur keluar $\left(\mathrm{T}_{\text {out }}\right)$, temperatur ambien $\left(\mathrm{T}_{\mathrm{amb}}\right)$, intensitas radiasi (rad), laju massa air $(\dot{m})$, dan luas kolektor (A) mempunyai pangaruh yang signifikan hal ini terlihat dari semua hasil pengujian nilai $\mathrm{T}_{\text {statistik }}>\mathrm{T}_{\text {critis }}$. Tingkat kepercayaan semua pengujian diatas $95 \%$ hal ini ditunjukan dengan hasil $\mathrm{P}_{\text {value }}$ yang sangat kecil.

Tabel 2. Rangkuman Nilai Statisik Kolektor.

\begin{tabular}{lccc}
\hline \multicolumn{1}{c}{ Pengujian } & $\mathbf{T}_{\text {stat }}$ & $\mathbf{T}_{\text {cri }}$ & $\mathbf{P}_{\text {value }}$ \\
\hline W/D $8 \mathrm{~mm}$ & 30.5 & 2.04 & $2.2 \times 10^{-47}$ \\
W 120 mm & 28.1 & 2.04 & $8.4 \times 10^{-42}$ \\
Kol. Pelat A $\mathrm{L}$ & 31.2 & 2.04 & $6.0 \times 10^{-44}$ \\
Kol. Horizontal & 37.6 & 2.04 & $5.2 \times 10^{-46}$ \\
Tanpa Kaca Penutup & 41.2 & 2.13 & $2.7 \times 10^{-27}$ \\
Mass flow 0,0075 kg/s & 36.4 & 2.13 & $9.0 \times 10^{-29}$ \\
\hline
\end{tabular}

\section{KESIMPULAN}

Efesiensi kolektor meningkat dengan adanya modifikasi jarak antar pipa riser yang lebih rapat, jenis material absorber yang memiliki konduktivitas termal yang tinggi, susunan pipa riser vertical yang membuat aliran lebih lama di dalam kolektor, menggunakan penutup kaca untuk menghindari perpindahan panas kolektor dengan udara lingkungan dan laju aliran massa yang lebih rendah.

Pressure drop yang tinggi menghasilkan efisiensi termal yang baik karena mengindifikasikan kontak fluida dengan panas pipa didalam kolektor lebih lama. Namun dari segi energi pompa ini merugikan.

\section{UCAPAN TERIMA KASIH}

Penulis mengucapkan terima kasih kepada Pembimbing beserta rekan-rekan mahasiswa Jurusan Teknik Mesin Universitas Lampung sehingga terlaksananya penelitian ini dengan baik.

\section{DAFTAR PUSTAKA}

[1] Biro Perencanaan dan Kerja Sama, 2015. Renstra KESDM 2015-2019. Kementerian Energi Sumber Daya Mineral.

[2] Kalogirou.Soteris., 2004, "Solar Energy Engineering”, Progress in Energy and Combustion, Science 30, 231-295.

[3] Duffie, J.A., dan Beckman, W.A., 2013, "Solar Engineering of Thermal Processes," $4^{\text {th }}$ edition., Hobokem, NJ: John Wiley \& Son, New York.

[4] K. K. Matrawi and I. Farkas., 1995, "Comparison Study for Three Types of Solar", Energy Convers. Mgmt Vol. 38, No. 9, pp. 861869.

[5] E. HAHNE, 1982, "Parameter Effects on Design and Performance of Flat Plate Solar Collectors” Solar Energy Vol. 34, No. 6, pp. 497-504.

[6] Ghamari, D.M., Worth, R.A., 1992, "The effect of tube spacing on the cost effectiveness of a flat-plate solar collector", Renewable Energy 2, 603-606. 
[7] M. Sumarsono, 2005, "Optimasi Jumlah PipaPemanas Terhadap Kinerja Kolektor Surya Pemanas Air”, Jurnal Ilmiah Teknologi Energi, Vol.1, No.1.

[8] S.N. Agbo dan C.E. Okeke, 2007, “correlations between collector Performance and tube spacing for various absorber plate material in natural circulation solar water heater" Trends in Applied Sciences Research 2 (3) : 251-254.

[9] P. Sivakumar, W. Christraj, M. Sridharan and N. Jayamalathi, 2012, "Performance Improvement Study of Solar Water Heating System”, ARPN Journal of Engineering and Applied Sciences, VOL. 7, NO. 1.

[10] X. A. Wang and L.G. Wu, 1990, "Analysis And Performance of Flat-Plat Solar Collector Arrays”, International Journal of Solar Energy Vol. 45, NO. 2. PP. 71o78.

[11] Volker Weitbrecht, David Lehmann and Andreas Richter, 2002, "Flow Distribution solar collectors with laminar flow conditions”, Solar Energy. 73(6): 433-441.

[12] S. Maharudrayya, S. Jayanti, A.P. Deshpande., 2005, "Flow distribution and pressure drop in parallel-channel configurations of planar fuel cells”, Journal of Power Sources 144 : 94-106.

[13] Federico Bava and Simon Furbo., 2016, “A numerical model for pressure drop and flow distribution in a solar collector with Uconnected absorber pipes”, Solar Energy 134 : 264-272.

[14] N.M.Nahar., 2001, "Capital cost and economic viability of thermosyphonic solar water heaters manufactured from alternate materials in India”, Renewable Energy 26 : 623-635.

[15] We He, Yang Zhang, Jie Ji, (2010)," Photovoltaic and thermal solar-collector designed for natural circulation of water. Applied Thermal Engineering 31 (2011) 33693376.

[16] Bonifacius, Nurhamdoko, (2012), “Optimalisasi Kondisi Termal dan Pembangkitan Energi pada Atap Photovoltaic Terintegrasi di Daerah Tropis Lembab”, Insititut Teknologi Sepuluh Nopember, Surabaya.

[17] Dunkle, R. V. and E. T. Davey, 1970, "Flow Distribution in Absorber Banks.” paper presented at Melbourne International Solar Energy SocietyConference.

[18] Chiou, J.P., 1982, "The effect of non-uniform fluid flow distribution on the thermal performance of solar collector”, Sol. Energy 29 (6), 487-502. 